\title{
Factors determining the upper limits of intertidal canopy-forming algae
}

\author{
S. J. Hawkins ${ }^{1}$ and R. G. Hartnoll ${ }^{2}$ \\ ${ }^{1}$ Department of Zoology, University of Manchester, Manchester M13 9PL, United Kingdom \\ ${ }^{2}$ Department of Marine Biology, University of Liverpool, Port Erin, Isle of Man, United Kingdom
}

\begin{abstract}
The causes of zonation of canopy-forming algae have been investigated by canopy removal experiments, combined with observations at the upper limits of various species on certain British shores during the exceptionally hot weather of summer 1983. Fucus vesiculosus, F. serratus and Laminaria digitata all extended their range upshore when the species zoned above were experimentally removed, indicating that competition can be directly responsible for setting upper limits of lowand mid-shore canopy algae. Removal of species zoned immediately below permitted down-shore extension of Pelvetia canaliculata, F. spiralis, $F$. vesiculosus, F. serratus and Himanthalia elongata, confirming the setting of lower limits of these species by competition. Amongst canopy-forming species, $P$. canaliculata, $F$. spiralis, $L$. saccharina, $L$. digitata and the 'button' stage of $H$. elongata showed signs of damage during summer 1983. There were no signs of damage to $F$. vesiculosus, $F$. serratus and Ascophyllum nodosum. Some species of low-shore, turf-forming understorey and encrusting red algae seemed more vulnerable to hot weather than the canopy-forming species. Corallina officinalis and 'lithothamnia' suffered extensive damage during summer 1983.
\end{abstract}

\section{INTRODUCTION}

It is generally accepted that the lower limits of the zones of intertidal plants and sessile animals are set by biological interactions such as competition for space, grazing and predation. However, until recently it was believed that physical 'emersion' factors, particularly heat and desiccation, were directly responsible for setting their upper limits (e.g. Connell, 1972; Carefoot, 1977; Underwood, 1979; Lubchenco, 1980; but see Hawkins and Hartnoll, 1983a for review of the role of grazing in setting upper limits). In this study, various manipulative experiments on algal-dominated areas of shore on the Isle of Man further tested whether the lower limits of fucoids were set by competition with the species zoned immediately below. More importantly, by means of additional experiments we investigated whether competition for space determined the upper limits of fucoids and Laminaria digitata.

Assessment of the importance of physical factors in setting the upper limits of intertidal algae was helped during 1983 by the hottest summer in the British Isles for 7 yr (meteorological records are presented in the appendix). Careful searches were made on the Isle of Man and in South-west England for damage or death of algae at their upper limits on the shore. If physical factors were directly setting these limits, then some extension up the shore would be expected during 1977-1982, followed by die-back caused by unusually hot weather in 1983.

Algal nomenclature follows Parke and Dixon (1976). 'Lithothamnia' is used as a collective name for all encrusting calcareous algae.

\section{METHODS}

The moderately-sheltered shore just south of the Albert Pier, Port St Mary, and the sheltered shore at Langness were both used for experiments. At Langness the fucoid zonation from top to bottom of the shore is Pelvetia canaliculata, Fucus spiralis, a very narrow $F$. vesiculosus band, Ascophyllum nodosum and $F$. serratus. At Port St Mary the sequence is F. spiralis, F. vesiculosus and $F$. serratus. A more exposed part of Kallow Point, where $F$. serratus directly abutted Laminaria digitata, was used for other experiments. Details of these shores are given in Southward (1953), Bruce et al. (1963) and Hawkins (1979). Lewis (1964) outlines general patterns of zonation on British shores.

Details of experiments are summarized in Tables 1 and 2. Areas of canopy were removed either above or 
below the zone of the species under test for extension of range. These experiments were usually started so as to coincide with the expected appearance of sporelings of the test species, based on the experience of previous monitoring and grazing exclusion experiments (Hawkins, 1981a, b; Hawkins and Hartnoll, 1983b). Usually the canopy was removed just once by cutting the plant at or just above the holdfast. Repeated selective removals were generally not possible as fucoid sporelings cannot be distinguished easily from each other until quite large. However, selective removal was possible in experiments involving competition between Fucus serratus and Laminaria digitata. In each experiment an untouched control area was designated nearby.

To avoid edge effects a $0.5 \mathrm{~m}$ to $1 \mathrm{~m}$ wide 'buffer zone' was cleared around the $2 \times 2 \mathrm{~m}$ areas used for the larger species (Fucus vesiculosus at the bottom of its range, F. serratus, Ascophyllum nodosum and Laminaria digitata). With the smaller plants of $F$. spiralis and $F$. vesiculosus at the top of its range, smaller areas of $1 \times 1 \mathrm{~m}$ were sufficient, though care was taken to remove adjacent plants whose fronds could sweep into the treatment area.

Throughout the period 1977-1983 evidence for damage or death of algae at their upper limits was looked for on the Isle of Man. From 1980 to 1983 observations were also made at various locations (listed in Table 3) in South-west England. In 1983, particularly careful searches were made on various shores in both areas during the hot weather of July and August. Damage to populations of each species was assessed on a subjective scale: no sign of bleaching or damage; bleaching and death of occasional plants in population; extensive bleaching and death of many plants.

\section{RESULTS}

Initial canopy compositions of each experiment are given in Tables 1 and 2. Further details of fauna and understorey algae can be found in Hawkins (1979).

Changes following canopy removal are summarized in Tables 1 and 2. Fucus spiralis, $F$. vesiculosus and $F$. serratus were all able to extend their range downshore after removal of the species zoned immediately below (Table 1). F. serratus and Laminaria digitata appeared further up the shore than normal in Experiments $4 \mathrm{c}$ and 5 respectively, even though these experiments were set up with the aim of inducing downshore extension in other species. F. vesiculosus and $L$. digitata were also enabled to extend higher up the shore by the removal of the species zoned above them (Table 2). No change in canopy composition was observed in any control area.

The meteorological data indicates that though June
1983 was duller than average, July 1983 was exceptionally hot, exceeding the summers of 1975 and 1976. In South-west England, August 1983 was much hotter than preceding years and approached the exceptional summer of 1976 - the latter being the hottest since recordings began at R.A.F. Mountbatten during the First World War. Generally, conditions were not so hot and sunny on the Isle of Man during 1983 as in South and South-west England. Most importantly, however, hot and sunny conditions coincided with low water springs during both July and August 1983 in all localities studied. Continuous hot and sunny weather also coincided with the neap tide periods of late July and early August.

Table 3 summarizes observations on the effects of the hot summer of 1983, together with observations in other years. Amongst the canopy algae, Laminaria digitata was the only species to show signs of drought bleaching in most years on the Isle of Man, and considerable damage was observed in 1983 both around Plymouth and on the Isle of Man. L. saccharina showed some signs of drought bleaching in 1983 in the Plymouth area and the Isle of Man. Whilst no effects were noted in 1983 on the adult plants of Himanthalia, the 'button' stage showed signs of bleaching in the Plymouth area. Pelvetia canaliculata and Fucus spiralis both appeared damaged in 1983 only. Ascophyllum nodosum, $F$. vesiculosus and $F$. serratus never showed any signs of damage at any of the localities studied.

Red algae, found in the sublittoral ringe or forming an understorey beneath Ascophyllum and Fucus serratus in the lower eulittoral, seemed more prone to drought damage (Table 3) than low- and mid-shore canopy algae. During July 1983, damage was particularly apparent in Corallina officinalis and 'Iithothamnia', especially plants at the rim of evaporating midtide rock pools. Occasionally, damaged plants of $\mathrm{Pal}$ maria palmata, Laurencia pinnatifida and Gigartina stellata were seen during 1983. All the species showing susceptibility to hot dry weather also died when protective canopies of Ascophyllum and $F$. serratus were removed (Tables 1 and 2; see Hawkins, 1979; Hawkins and Harkin, in press, for further details). 'Lithothamnia' were also noticed to extend higher up the shore under Fucus patches induced by grazerremoval experiments on the Isle of Man (Hawkins, 1979, 1981a, b) and following kills of limpets caused by the 'Torrey Canyon' clean-up using toxic dispersants (Southward and Southward, 1978).

Ephemeral algae high in the littoral fringe were bleached completely and died back in the summers of most years (Table 3; Hawkins and Hartnoll, 1983b).

Many other species of intertidal algae, not listed in Table 3, seemed unaffected by the unusually hot weather of 1983. 
Table 1. Details of design and summary of results of experiments testing the setting of lower limits by competition

\begin{tabular}{|c|c|c|c|c|c|c|c|}
\hline $\begin{array}{l}\text { Experiment no. } \\
\text { and date }\end{array}$ & Site & Initial canopy & Size & Design & Hypothesis & $\begin{array}{ll}\text { Canopy } & \text { Results }\end{array}$ & Understorey \\
\hline (1) Apr 1978 & Langness & $\begin{array}{l}100 \% \\
\text { F. spiralis } \\
\text { immediately } \\
\text { below Pelvetia }\end{array}$ & $1 \mathrm{~m}^{2}$ & $\begin{array}{l}\text { Cleared } \\
\text { once }\end{array}$ & $\begin{array}{l}\text { F. spiralis } \\
\text { limits } \\
\text { downshore } \\
\text { extension of } \\
\text { Pelvetia }\end{array}$ & $\begin{array}{l}\text { Some Pelvetia (max. } \\
10 \% \text { cover) appeared } \\
\text { but swamped by } \\
\text { recolonizing } \\
\text { F. spiralis }\end{array}$ & $\begin{array}{l}\text { No understorey- } \\
\text { some growth of } \\
\text { green algae } \\
\text { upon canopy } \\
\text { removal. No } \\
\text { change in control }\end{array}$ \\
\hline (2) Nov 1977 & Langness & $\begin{array}{l}100 \% \\
\text { F. vesiculosus } \\
\text { immediately } \\
\text { below } \\
\text { F. spiralis }\end{array}$ & $1 \mathrm{~m}^{2}$ & $\begin{array}{l}\text { Cleared } \\
\text { once }\end{array}$ & $\begin{array}{l}\text { F. vesiculosus } \\
\text { limits } \\
\text { downshore } \\
\text { extension of } \\
\text { F. spiralis }\end{array}$ & $\begin{array}{l}F \text {. vesiculosus } \\
\text { recolonized rapidly } \\
\text { but no } F \text {. spiralis } \\
\text { observed }\end{array}$ & $\begin{array}{l}\text { No understorey- } \\
\text { some growth of } \\
\text { green algae. } \\
\text { No change in } \\
\text { control }\end{array}$ \\
\hline (3) Nov 1977 & $\begin{array}{l}\text { Port St Mary } \\
\text { sheltered }\end{array}$ & $\begin{array}{l}100 \% \\
F . \text { vesiculosus } \\
\text { immediately } \\
\text { below } \\
\text { F. spiralis }\end{array}$ & $1 \mathrm{~m}^{2}$ & $\begin{array}{l}\text { Cleared } \\
\text { once }\end{array}$ & $\begin{array}{l}F . \text { vesiculosus } \\
\text { limits } \\
\text { downshore } \\
\text { extension of } \\
\text { F. spiralis }\end{array}$ & $\begin{array}{l}40-50 \% \text { F. spiralis } \\
\text { established one year } \\
\text { later, eventually } \\
\text { swamped by } \\
\text { F. vesiculosus }\end{array}$ & $\begin{array}{l}\text { No understorey- } \\
\text { some growth of } \\
\text { green algae. } \\
\text { No change in } \\
\text { control }\end{array}$ \\
\hline (4a) Nov 1978 & Langness & $\begin{array}{l}90 \% \\
\text { Ascophyllum, } \\
\text { and } 10 \% \\
\text { F. vesiculosus } \\
\text { zoned below } \\
100 \%\end{array}$ & $2 \times 2 \mathrm{~m}$ & $\begin{array}{l}\text { All } \\
\text { cleared } \\
\text { once }\end{array}$ & $\begin{array}{l}\text { Ascophyllum } \\
\text { limits } \\
\text { downshore } \\
\text { extension of } \\
\text { F. vesiculosus }\end{array}$ & $\begin{array}{l}\text { (a) } F \text {. vesiculosus } \\
\text { achieved } 80 \% \text { cover } \\
\text { after } 1 \mathrm{y}\end{array}$ & $\begin{array}{l}\text { In all replicates } \\
\text { understorey } \\
\text { algae such as } \\
\text { 'Lithothamnia' } \\
\text { and Corallina } \\
\text { died in spring }\end{array}$ \\
\hline b Apr 1978 & & $F$. vesiculosus & $2 \times 2 \mathrm{~m}$ & & & $\begin{array}{l}\text { (b) } F \text {. vesiculosus } \\
\text { achieved } 80 \% \text { cover } \\
\text { after } 1 \text { y }\end{array}$ & $\begin{array}{l}\text { and summer. } \\
\text { No change in } \\
\text { controls }\end{array}$ \\
\hline c Aug 1978 & & & $3 \times 2 \mathrm{~m}$ & & & $\begin{array}{l}\text { (c) F. vesiculosus } \\
\text { achieved } 80 \% \text { cover; } \\
\text { some F. serratus } \\
\text { (10\% cover) extended } \\
\text { upwards after } 1 \text { y }\end{array}$ & \\
\hline $\begin{array}{l}\text { (5) Aug } 1977 \\
\text { See Hawkins } \\
\text { \& Harkin } \\
\text { (in press) } \\
\text { for further } \\
\text { details }\end{array}$ & $\begin{array}{l}\text { Port St Mary } \\
\text { exposed }\end{array}$ & $\begin{array}{l}100 \% \\
\text { F. serratus } \\
\text { some way } \\
\text { from a patchy } \\
\text { F. vesiculosus/ } \\
\text { barnacle zone }\end{array}$ & $2 \times 2 \mathrm{~m}$ & $\begin{array}{l}\text { Cleared } \\
\text { once }\end{array}$ & $\begin{array}{l}\text { F. serratus } \\
\text { limits } \\
\text { downshore } \\
\text { extension of } \\
\text { F. vesiculosus }\end{array}$ & $\begin{array}{l}\text { No } F . \text { vesiculosus } \\
\text { found. Laminaria } \\
\text { digitata sporelings } \\
\text { survived, reaching } \\
0.5 \mathrm{~m} \text { long and } 5 \% \\
\text { cover Though } \\
\text { bleached in summer, } \\
\text { plants survived } 1 \mathrm{y} \\
\text { later. Laminaria } \\
\text { sporelings in control } \\
\text { did not grow }\end{array}$ & $\begin{array}{l}\text { 'Lithothamnia' } \\
\text { died, rapid } \\
\text { growth of } \\
\text { Enteromorph } \\
\text { and Palmaria. } \\
\text { No change in } \\
\text { control }\end{array}$ \\
\hline (6) Oct 1978 & $\begin{array}{l}\text { Port St Mary } \\
\text { sheltered }\end{array}$ & $\begin{array}{l}80 \% \\
\text { Laminaria, } \\
20 \% \\
\text { F. serratus }\end{array}$ & $2 \times 8 \mathrm{~m}$ & $\begin{array}{l}\text { Lamina- } \\
\text { ria re- } \\
\text { peatedly } \\
\text { removed }\end{array}$ & $\begin{array}{l}\text { L. digitata } \\
\text { limits } \\
\text { downshore } \\
\text { extension of } \\
\text { F. serratus }\end{array}$ & $\begin{array}{l}\text { F. serratus and } \\
\text { Himanthalia extended } \\
\text { range downshore. } \\
\text { F. serratus forming } \\
100 \% \text { cover where } \\
\text { previously } 20 \% \text { after } \\
1 \text { y }\end{array}$ & $\begin{array}{l}\text { Even though } \\
\text { canopy removal } \\
\text { in autumn, } \\
\text { 'Lithothamnia' } \\
\text { died. No change } \\
\text { in control }\end{array}$ \\
\hline
\end{tabular}

\section{DISCUSSION}

The long-standing hypotheses that competition can set the lower limits of canopy forming algae in the inter-tidal (e.g. reviews by Southward, 1958; Lewis, 1964) have more recently been experimentally confirmed by other workers (e.g. Menge, 1975; Lub- chenco, 1980; Schonbeck and Norton, 1980) and now ourselves (see also Hawkins and Harkin, in press). Ascophyllum, however, still remains enigmatic. Very few viable sporelings of Ascophyllum are found on the shore (Burrows, 1947; Hawkins, 1979; Schonbeck and Norton, 1980) making it an unsuitable subject for manipulative experiments. It recolonizes its own zone 
Table 2. Details of design and summary of results of experiments testing the setting of upper limits by competition

\begin{tabular}{|c|c|c|c|c|c|c|c|}
\hline \multirow{2}{*}{$\begin{array}{l}\text { Experiment no. } \\
\text { and date }\end{array}$} & \multirow[t]{2}{*}{ Site } & \multirow[t]{2}{*}{ Initial canopy } & \multirow[t]{2}{*}{ Size } & \multirow[t]{2}{*}{ Design } & \multirow[t]{2}{*}{ Hypothesis } & \multicolumn{2}{|c|}{ Results } \\
\hline & & & & & & Canopy & Understorey \\
\hline $\begin{array}{l}\text { (7) Apr } 1978, \\
\text { replicates a \& b }\end{array}$ & Langness & $\begin{array}{l}100 \% \\
\text { F. spiralis } \\
\text { imumediately } \\
\text { above } \\
\text { F. vesiculosus }\end{array}$ & $1 \mathrm{~m}^{2}$ & $\begin{array}{l}\text { Cleared } \\
\text { once }\end{array}$ & $\begin{array}{l}\text { F. spiralis } \\
\text { limits upshore } \\
\text { extension of } \\
F . \text { vesiculosus }\end{array}$ & $\begin{array}{l}\text { (a) } 1 \text { plant of } \\
F \text {. vesiculosus } \\
\text { established and } \\
\text { survived } \\
1 \text { y } \\
\text { (b) } 5-10 \% \text { cover } \\
\text { of } F \text {. vesiculosus } \\
\text { became } \\
\text { established and } \\
\text { survived } \\
1 y\end{array}$ & $\begin{array}{l}\text { Catenella died, } \\
\text { some green } \\
\text { algae appeared. } \\
\text { No change in } \\
\text { Catenella in } \\
\text { control }\end{array}$ \\
\hline (8) Nov 1978 & $\begin{array}{l}\text { Port St Máry } \\
\text { sheltered }\end{array}$ & $\begin{array}{l}100 \% \\
\text { F. vesiculosus } \\
\text { immediately } \\
\text { above } \\
\text { F. serratus }\end{array}$ & $2 \times 2 \mathrm{~m}$ & $\begin{array}{l}\text { Cleared } \\
\text { once }\end{array}$ & $\begin{array}{l}\text { F. vesiculosus } \\
\text { limits upshore } \\
\text { extension of } \\
\text { F. serratus }\end{array}$ & $\begin{array}{l}20 \% \text { cover of } \\
\text { F. serratus } \\
\text { sporelings } 6 \mathrm{~m} \\
\text { later } 10-15 \% \\
\text { after } 1 \mathrm{y}\end{array}$ & $\begin{array}{l}\text { 'Lithothaminia' } \\
\text { and few } \\
\text { L. digitata } \\
\text { sporelings died, } \\
\text { no change in } \\
\text { control }\end{array}$ \\
\hline (9) Nov 1978 & $\begin{array}{l}\text { Port St Mary } \\
\text { exposed }\end{array}$ & $\begin{array}{l}95 \% \\
\text { F. serratus and } \\
5 \% \text { L. digitata } \\
\text { zoned above } \\
50 \% \\
\text { L. digitata and } \\
50 \% \\
\text { F. serratus }\end{array}$ & $2 \times 1 \mathrm{~m}$ & $\begin{array}{l}\text { Cleared } \\
\text { once }\end{array}$ & $\begin{array}{l}\text { F. serratus } \\
\text { limits upshore } \\
\text { extension of } \\
\text { L. digitata }\end{array}$ & $\begin{array}{l}20 \% \text { L. digitata } \\
\text { in May, } 6 \mathrm{~m} \\
\text { later, some } \\
\text { bleaching in } \\
\text { summer but } \\
\text { survived and } \\
\text { achieved } 25 \% \\
\text { cover after } 1 \mathrm{y}\end{array}$ & $\begin{array}{l}\text { 'Lithothamnia' } \\
\text { died, but not in } \\
\text { control }\end{array}$ \\
\hline
\end{tabular}

very slowly (Burrows, 1947; Hawkins, 1979; Boaden and Dring, 1980) and sporelings were never found in various Fucus serratus removals (not all detailed here, but see Hawkins, 1979). The factors setting the lower limit of Ascophyllum remain unclear. Greater water movement and depth may be directly unfavourable to it, preventing formation of dense monospecific stands of large plants. Indirectly, greater water movement may increase Patella numbers and hence grazing pressure, and also enhance sweeping by $F$. serratus; both may prevent establishment of Ascophyllum sporelings.

More interestingly, our work shows that on sheltered shores, the upper limits of Fucus serratus and F. vesiculosus are set directly by competition with the species zoned immediately above. The upper limits of Laminaria digitata can be directly set by competition acting on sporelings; though extremes of both hot (our study) and cold weather (Todd and Lewis, 1984) can also cause kills of adult plants at their upper limit. Extreme physical stress, however, does definitely set the upper limits of the high-shore canopy forming algae Pelvetia canaliculata and $F$. spiralis. The upper limits of both these species at Port St Mary, Isle of Man were raised during the cool damp summers of 1978-1982 (S. J. Hawkins, unpubl.), whereas in 1983 there was die-back of both these species at several localities. Schonbeck and Norton (1978) similarly reported trimming back of zones of Pelvetia and F. spiralis during hot weather in 1975 and 1976. In contrast to us, however, they reported die-back of Ascophyllum at its upper limit, which we did not observe in 1983. They also found no deaths of $F$. serratus at their upper limit.

Other work, primarily concerned with grazing, has also shown that upper limits of some mid and low shores species are not set directly by physical factors (for review see Hawkins and Hartnoll, 1983a). In particular a mixture of Fucus species, with F. serratus far above its normal zone, can be seen after limpet removal (Burrows and Lodge, 1950; Hawkins, 1981b). Laminaria digitata and Himanthalia elongata were found much higher up the shore as a consequence of limpet kills following the Torrey Canyon (Southward and Southward, 1978). Colonization of new substrata is also informative. All 3 species of Fucus were found side by side on 2 yr old blocks on Plymouth Breakwater (Hawkins and Southward, unpubl.). In contrast, only $F$. vesiculosus in small patches was found at similar shore levels on older blocks ( $>20 \mathrm{yr}$ ) and on the Breakwater itself ( $>150 \mathrm{yr}$ ). Mixed zonation was also found on new harbour works at Port Erin, Isle of Man (Hawkins, 1979) and at Hunterston, Scotland (Clokie and Boney, 1980). During succession, several years are needed 
Table 3. Effects of drought on intertidal algae at their upper limits. ( - no effects; + signs of damage or death; ++ severe damage $_{i} /$ no observations)

\begin{tabular}{|c|c|c|c|c|c|c|}
\hline \multirow[t]{3}{*}{ Species } & \multicolumn{6}{|c|}{ Location } \\
\hline & \multicolumn{2}{|c|}{ Isle of $\operatorname{Man}$} & \multirow{2}{*}{$\begin{array}{l}\text { Plymouth } \\
1983\end{array}$} & \multirow{2}{*}{$\begin{array}{c}\text { N. Devon \& } \\
\text { N. Cornwall } \\
1983\end{array}$} & \multicolumn{2}{|c|}{ Swanage } \\
\hline & $1977-82$ & 1983 & & & $1980-82$ & 1983 \\
\hline \multicolumn{7}{|l|}{ Littoral fringe species } \\
\hline Blidingia minima & + & + & + & + & + & + \\
\hline Enteromorpha spp. & + & + & + & + & + & + \\
\hline Porphyra spp. & + & + & + & + & + & + \\
\hline Prasiola stipitata & + & + & + & + & + & + \\
\hline Ulothrix/Urospora & + & + & ' & 1 & + & + \\
\hline \multicolumn{7}{|l|}{ Eulittoral canopy species } \\
\hline Pelvetia canaliculata & - & + & + & / & 1 & / \\
\hline Fucus spiralis & - & + & + & 1 & - & + \\
\hline$F$ vesiculosus & - & - & - & - & - & - \\
\hline Ascophyllum nodosum & - & - & - & / & 1 & / \\
\hline Himanthalia elongata & - & - & + 'Buttons' & - & - & - \\
\hline$F$. serratus & - & - & - & - & - & - \\
\hline \multicolumn{7}{|c|}{ Sublittoral fringe canopy species } \\
\hline Laminaria digitata & + & ++ & $+t$ & / & - & + \\
\hline L. saccharina & - & + & + & I & 1 & / \\
\hline Polyschides sacchoriza & / & 1 & - & 1 & / & / \\
\hline L. hyperborea & - & - & - & ' & ' & ' \\
\hline \multicolumn{7}{|c|}{$\begin{array}{l}\text { Sublittoral fringe and low-shore turf and } \\
\text { mid-shore understorey species }\end{array}$} \\
\hline Laurencia pinnatifida & - & + & + & - & - & - \\
\hline Gigartina stellata & - & + & + & - & - & + \\
\hline Chondrus crispus & - & - & - & - & - & - \\
\hline Corallina officinalis & + & $+t$ & ++ & $+t$ & - & $+t$ \\
\hline 'Lithothamnia' & + & ++ & ++ & ++ & + & ++ \\
\hline Palmaria palmata & - & - & + & 1 & / & 1 \\
\hline
\end{tabular}

before grazing or competition (sometimes acting together) sort out zonation patterns.

Consideration of the factors setting upper limits of low-shore turf-forming algae or encrustations is more problematic. They are often found higher up the shore under canopies or on shaded rocks, and Dayton (1975) considered them in that situation as an 'obligate understorey' since they invariably die when their protective canopy is removed. Not surprisingly, many of these species on open lower-shore rock showed signs of damage or death at their upper limits during 1983. Desiccation can be considered responsible for the death of species such as Corallina officinalis, Chondrus crispus and Gigartina stellata as very shallow pools or trickles of water can result in extension much higher up the shore than on well-drained surfaces. On the Isle of Cumbrae in Scotland porous sandstone probably enables Chondrus and Gigartina to extend much higher upshore than is usual (S.J.H. pers. obs.). Some of the more delicate reds, such as Lomentaria, may be true 'shade plants' in that they are damaged by high light intensities rather than desiccation. These 2 factors are hard to separate and need further investiga- tion. Several turf-forming species extended higher up on an exposed shore following limpet kills after the Torrey Canyon oil spill (Southward and Southward, 1978). Various turf algae have also been induced by experimental grazer removal to grow higher up the shore during the winter and damp summers on more moderately exposed shores on the Isle of Man ( $\mathrm{Pal}$ maria palmata, Ceramium sp.; Hawkins, 1979, 1981b) and at Swanage (Ceramium sp., Laurencia pinnatifida, Cladostephus; S.J.H. pers. obs.). Together these observations suggest that except in occasional extreme conditions, grazing rather than physical restrictions sets the upper limit of such species.

Littoral fringe algae usually die-back every summer (see also Hawkins and Hartnoll, 1983b). They leave what appears to be bare rock, though it is likely that some species (perhaps members of Blidingia and Enteromorpha) may be able to regrow from the microscopic remains of bases. Other species, such as those of Porphyra and Ulothrix, may be completely killed off; though they probably recruit from alternate stages in their life histories (Lubchenco and Cubit, 1980) that occur lower on the shore during the summer, which are 
either burrowing ('Conchocoelis' phase of Porphyra) or prostrate (Ulothrix).

Low-water springs occur in the middle of the day $(1000$ to $1300 \mathrm{~h})$ at the sites on the north coasts of Devon and Cornwall, and around Plymouth. In contrast, on the Isle of Man they are in the early morning and evening (0500 to 0800 and 1700 to $2000 \mathrm{~h}$ ) and at Swanage in the late afternoon and very early morning (1500 to 1800 and 0300 to $0600 \mathrm{~h}$ ). Comparisons between the Isle of Man and South-West England are difficult to make because of latitudinal differences in summer conditions (see Lewis, 1964 and appendix) differences which were apparent in 1983. The weather in 1983 at Swanage, however, was very similar to that at Plymouth. So it is interesting to note that drought damage, particularly in Laminaria digitata, was less marked at Swanage. This confirms the long-standing hypothesis of Lewis (1964) that the timing of low water springs can be a factor affecting the distribution and abundance of low shore species.

APPENDIX: Summary of mean monthly maximum air temperatures ${ }^{\circ} \mathrm{C}$ (Tmax) and total sunshine hours (S h) during Jun, Jul and Aug 1975 to 1983 . Deviations from 30 yr average given in brackets. $\mathrm{I}_{\mathrm{T}}$ is an index of temperature anomaly derived by summing the differences of the $30 \mathrm{Yr}$ average from the observed figure for Jun, Jul, Aug. $\mathrm{I}_{\mathrm{S}}$ is an index of total sunshine hours anomaly derived by summing the differences of the 30 yr average from the observed figure for Jun, Jul, Aug

\begin{tabular}{|c|c|c|c|c|c|c|c|c|}
\hline & \multicolumn{8}{|c|}{ Ronaldsway } \\
\hline & \multicolumn{2}{|c|}{ Jun } & \multicolumn{2}{|c|}{ Jul } & \multicolumn{2}{|c|}{ Aug } & \multirow[b]{2}{*}{$\mathrm{I}_{\mathrm{T}}$} & \multirow[b]{2}{*}{$I_{S}$} \\
\hline & $T_{\max }$ & Sh & Tmax. & Sh & $T \max$. & $\mathrm{Sh}$ & & \\
\hline 975 & $\begin{array}{c}17.2 \\
(+1.1)\end{array}$ & $\begin{array}{c}303 \\
(+89)\end{array}$ & $\begin{array}{c}18.5 \\
(+1.2)\end{array}$ & $\begin{array}{c}187 \\
(-4)\end{array}$ & $\begin{array}{c}19.3 \\
(+2.0)\end{array}$ & $\begin{array}{c}202 \\
(+23)\end{array}$ & +5.8 & +10 \\
\hline 1976 & $\begin{array}{c}16.3 \\
(+0.2)\end{array}$ & $\begin{array}{c}199 \\
(-15)\end{array}$ & $\begin{array}{c}19.5 \\
(+2.2)\end{array}$ & $\begin{array}{c}228 \\
(+37)\end{array}$ & $\begin{array}{c}20.7 \\
(+3.4)\end{array}$ & $\begin{array}{c}273 \\
(+94)\end{array}$ & +9.5 & +11 \\
\hline 977 & $\begin{array}{c}15.6 \\
(-0.5)\end{array}$ & $\begin{array}{c}232 \\
(+18)\end{array}$ & $\begin{array}{c}18.4 \\
(+1.1)\end{array}$ & $\begin{array}{c}211 \\
(+20)\end{array}$ & $\begin{array}{c}18.0 \\
(+0.7)\end{array}$ & $\begin{array}{c}228 \\
(+49)\end{array}$ & -0.9 & +8 \\
\hline 978 & $\begin{array}{c}15.5 \\
(-0.6)\end{array}$ & $\begin{array}{c}169 \\
(-35)\end{array}$ & $\begin{array}{c}16.2 \\
(-0.9)\end{array}$ & $\begin{array}{c}175 \\
(-16)\end{array}$ & $\begin{array}{c}16.3 \\
(-1.0)\end{array}$ & $\begin{array}{c}129 \\
(-50)\end{array}$ & -2.3 & -101 \\
\hline 979 & $\begin{array}{c}15.3 \\
(-0.8)\end{array}$ & $\begin{array}{c}212 \\
(-2)\end{array}$ & $\begin{array}{c}16.6 \\
(-0.3)\end{array}$ & $\begin{array}{c}139 \\
(-52)\end{array}$ & $\begin{array}{c}15.9 \\
(-1.4)\end{array}$ & $\begin{array}{c}184 \\
(+5)\end{array}$ & -1.2 & -49 \\
\hline 980 & $\begin{array}{c}15.1 \\
(-1.0)\end{array}$ & $\begin{array}{c}177 \\
(-37)\end{array}$ & $\begin{array}{c}16.6 \\
(-0.7)\end{array}$ & $\begin{array}{c}179 \\
(-12)\end{array}$ & $\begin{array}{c}16.7 \\
(-0.6)\end{array}$ & $\begin{array}{c}127 \\
(-52)\end{array}$ & +0.5 & -101 \\
\hline 981 & $\begin{array}{c}14.5 \\
(-1.6)\end{array}$ & $\begin{array}{c}183 \\
(-31)\end{array}$ & $\begin{array}{c}16.6 \\
(-0.7)\end{array}$ & $\begin{array}{c}156 \\
(-35)\end{array}$ & $\begin{array}{c}17.4 \\
(+0.1)\end{array}$ & $\begin{array}{c}174 \\
(-5)\end{array}$ & +0.6 & -71 \\
\hline 982 & $\begin{array}{c}16.4 \\
(+0.3)\end{array}$ & $\begin{array}{c}187 \\
(-27)\end{array}$ & $\begin{array}{c}18.8 \\
(+1.5)\end{array}$ & $\begin{array}{c}196 \\
(+5)\end{array}$ & $\begin{array}{c}17.6 \\
(+0.3)\end{array}$ & $\begin{array}{c}180 \\
(+1)\end{array}$ & +0.9 & -21 \\
\hline 983 & $\begin{array}{c}15.8 \\
(-0.3)\end{array}$ & $\begin{array}{c}196 \\
(-18)\end{array}$ & $\begin{array}{c}20.4 \\
(+3.1)\end{array}$ & $\begin{array}{c}224 \\
(+33)\end{array}$ & $\begin{array}{c}19.4 \\
(+2.1)\end{array}$ & $\begin{array}{c}209 \\
(+30)\end{array}$ & +8.5 & +45 \\
\hline eras & 16.1 & 214 & 17.3 & 191 & 17.3 & 179 & & \\
\hline
\end{tabular}

$951-80$

\begin{tabular}{|c|c|c|c|c|c|c|c|c|}
\hline & \multicolumn{8}{|c|}{ Plymouth } \\
\hline & \multicolumn{2}{|c|}{ Jun } & \multicolumn{2}{|c|}{ JuI } & \multicolumn{2}{|c|}{ Aug } & \multirow[b]{2}{*}{$\mathrm{I}_{\mathrm{\tau}}$} & \multirow[b]{2}{*}{$I_{s}$} \\
\hline & $T \max$ & Sh & Tmax. & $\mathrm{Sh}$ & Tmax. & Sh & & \\
\hline 1975 & $\begin{array}{c}19.3 \\
(+2.2)\end{array}$ & $\begin{array}{c}331 \\
(+109)\end{array}$ & $\begin{array}{c}20.3 \\
(+1.2)\end{array}$ & $\begin{array}{c}244 \\
(+31)\end{array}$ & $\begin{array}{c}21.3 \\
(+2.2)\end{array}$ & $\begin{array}{c}193 \\
(-3)\end{array}$ & +5.6 & +137 \\
\hline 1976 & $\begin{array}{c}20.2 \\
(+2.6)\end{array}$ & $\begin{array}{c}255 \\
(+33)\end{array}$ & $\begin{array}{c}21.8 \\
(+2.7)\end{array}$ & $\begin{array}{c}260 \\
(+47)\end{array}$ & $\begin{array}{c}23.3 \\
(+4.2)\end{array}$ & $\begin{array}{c}308 \\
(+112)\end{array}$ & +9.3 & +192 \\
\hline 1977 & $\begin{array}{c}15.7 \\
(-1.9)\end{array}$ & $\begin{array}{c}163 \\
(-59)\end{array}$ & $\begin{array}{c}19.8 \\
(+0.7)\end{array}$ & $\begin{array}{c}223 \\
(+10)\end{array}$ & $\begin{array}{c}19.2 \\
(+0.1)\end{array}$ & $\begin{array}{c}212 \\
(-16)\end{array}$ & -1.1 & -65 \\
\hline 1978 & $\begin{array}{c}17.1 \\
(-0.5)\end{array}$ & $\begin{array}{c}216 \\
(-8)\end{array}$ & $\begin{array}{c}17.4 \\
(-1.7)\end{array}$ & $\begin{array}{c}145 \\
(-84)\end{array}$ & $\begin{array}{c}18.8 \\
(-0.3)\end{array}$ & $\begin{array}{c}220 \\
(+24)\end{array}$ & -2.5 & -68 \\
\hline 1979 & $\begin{array}{c}16.4 \\
(-1.2)\end{array}$ & $\begin{array}{c}172 \\
(-52)\end{array}$ & $\begin{array}{c}19.9 \\
(+0.8)\end{array}$ & $\begin{array}{c}237 \\
(+24)\end{array}$ & $\begin{array}{c}18.1 \\
(-1.0)\end{array}$ & $\begin{array}{c}194 \\
(+2)\end{array}$ & -1.4 & -26 \\
\hline 980 & $\begin{array}{c}16.8 \\
(-0.8)\end{array}$ & $\begin{array}{c}175 \\
(-48)\end{array}$ & $\begin{array}{c}17.5 \\
(+1.4)\end{array}$ & $\begin{array}{c}177 \\
(-36)\end{array}$ & $\begin{array}{c}18.8 \\
(-0.3)\end{array}$ & $\begin{array}{c}167 \\
(-29)\end{array}$ & +0.3 & -123 \\
\hline 1981 & $\begin{array}{c}16.3 \\
(-1.3)\end{array}$ & $\begin{array}{c}197 \\
(-26)\end{array}$ & $\begin{array}{c}18.9 \\
(-0.2)\end{array}$ & $\begin{array}{c}164 \\
(-49)\end{array}$ & $\begin{array}{c}20.8 \\
(+1.7)\end{array}$ & $\begin{array}{c}241 \\
(+45)\end{array}$ & +0.7 & -31 \\
\hline 1982 & $\begin{array}{c}17.9 \\
(+0.3)\end{array}$ & $\begin{array}{c}203 \\
(-20)\end{array}$ & $\begin{array}{c}20.1 \\
(+1.0)\end{array}$ & $\begin{array}{c}165 \\
(-48)\end{array}$ & $\begin{array}{c}18.5 \\
(-0.6)\end{array}$ & $\begin{array}{c}155 \\
(-41)\end{array}$ & +0.7 & -109 \\
\hline 1983 & $\begin{array}{c}17.8 \\
(+0.2)\end{array}$ & $\begin{array}{c}180 \\
(-43)\end{array}$ & $\begin{array}{c}24.0 \\
(+4.9)\end{array}$ & $\begin{array}{c}290 \\
(+77)\end{array}$ & $\begin{array}{c}22.3 \\
(+3.2)\end{array}$ & $\begin{array}{c}280 \\
(+84)\end{array}$ & +8.3 & +188 \\
\hline $\begin{array}{l}\text { verage } \\
951-80\end{array}$ & 17.6 & 222 & 19.1 & 213 & 19.1 & 196 & & \\
\hline
\end{tabular}

\begin{tabular}{|c|c|c|c|c|c|c|c|c|}
\hline & & & & acom & & & & \\
\hline & $\mathrm{JL}$ & un & $\mathrm{J}$ & ul & Al & ug & & \\
\hline & Tmax. & Sh & Tmax. & $\mathrm{Sh}$ & $T \max$ & Sh & $\mathrm{I}_{\mathrm{T}}$ & $\mathrm{I}_{\mathrm{S}}$ \\
\hline 975 & $\begin{array}{c}18.5 \\
(+1.3)\end{array}$ & $\begin{array}{c}301 \\
(+75)\end{array}$ & $\begin{array}{c}20.0 \\
(+1.4)\end{array}$ & $\begin{array}{c}235 \\
(+25)\end{array}$ & $\begin{array}{c}20.7 \\
(+1.7)\end{array}$ & $\begin{array}{c}152 \\
(-40)\end{array}$ & +4.4 & +60 \\
\hline 1976 & $\begin{array}{c}19.0 \\
(+1.8)\end{array}$ & $\begin{array}{c}235 \\
(+9)\end{array}$ & $\begin{array}{c}21.6 \\
(+3.0)\end{array}$ & $\begin{array}{c}260 \\
(+50)\end{array}$ & $\begin{array}{c}22.1 \\
(+3.1)\end{array}$ & $\begin{array}{c}333 \\
(+141)\end{array}$ & +7.9 & +200 \\
\hline 1977 & $\begin{array}{c}15.4 \\
(-1.8)\end{array}$ & $\begin{array}{c}179 \\
(-47)\end{array}$ & $\begin{array}{c}19.1 \\
(+0.5)\end{array}$ & $\begin{array}{c}234 \\
(+24)\end{array}$ & $\begin{array}{c}19.1 \\
(+0.1)\end{array}$ & $\begin{array}{c}196 \\
(+4)\end{array}$ & -1.2 & -19 \\
\hline 1978 & $\begin{array}{c}16.8 \\
(-0.4)\end{array}$ & $\begin{array}{c}199 \\
(-27)\end{array}$ & $\begin{array}{c}17.1 \\
(-1.5)\end{array}$ & $\begin{array}{c}147 \\
(-63)\end{array}$ & $\begin{array}{c}18.7 \\
(-0.3)\end{array}$ & $\begin{array}{c}186 \\
(-6)\end{array}$ & -2.2 & -96 \\
\hline 1979 & $\begin{array}{c}16.7 \\
(-0.5)\end{array}$ & $\begin{array}{c}181 \\
(-45)\end{array}$ & $\begin{array}{c}18.7 \\
(+0.1)\end{array}$ & $\begin{array}{c}212 \\
(+2)\end{array}$ & $\begin{array}{c}18.2 \\
(-0.8)\end{array}$ & $\begin{array}{c}133 \\
(-59)\end{array}$ & -1.2 & -102 \\
\hline 980 & $\begin{array}{c}16.7 \\
(-0.5)\end{array}$ & $\begin{array}{c}176 \\
(-50)\end{array}$ & $\begin{array}{c}17.7 \\
(-0.9)\end{array}$ & $\begin{array}{c}166 \\
(-44)\end{array}$ & $\begin{array}{l}19.0 \\
(0.0)\end{array}$ & $\begin{array}{c}146 \\
(-46)\end{array}$ & -1.4 & -140 \\
\hline 1981 & $\begin{array}{c}16.2 \\
(-1.0)\end{array}$ & $\begin{array}{c}163 \\
(-63)\end{array}$ & $\begin{array}{c}17.6 \\
(-1.0)\end{array}$ & $\begin{array}{c}152 \\
(-56)\end{array}$ & $\begin{array}{c}19.3 \\
(+0.3)\end{array}$ & $\begin{array}{c}203 \\
(+11)\end{array}$ & -2.3 & -108 \\
\hline 1982 & $\begin{array}{c}18.3 \\
(+1.1)\end{array}$ & $\begin{array}{c}171 \\
(-54)\end{array}$ & $\begin{array}{c}19.2 \\
(+0.6)\end{array}$ & $\begin{array}{c}170 \\
(-40)\end{array}$ & $\begin{array}{c}18.5 \\
(-0.5)\end{array}$ & $\begin{array}{c}115 \\
(-77)\end{array}$ & +1.2 & -171 \\
\hline 1983 & $\begin{array}{l}17.2 \\
(0.0)\end{array}$ & $\begin{array}{c}162 \\
(-64)\end{array}$ & $\begin{array}{c}22.1 \\
(+3.5)\end{array}$ & $\begin{array}{c}299 \\
(+89)\end{array}$ & $\begin{array}{c}21.3 \\
(+2.3)\end{array}$ & $\begin{array}{c}262 \\
(+70)\end{array}$ & +5.8 & +95 \\
\hline $\begin{array}{l}y \mathrm{y} \\
\text { erage } \\
51-8\end{array}$ & 17.2 & 226 & 18.6 & 210 & 19.0 & 192 & & \\
\hline
\end{tabular}

\begin{tabular}{|c|c|c|c|c|c|c|c|c|}
\hline & \multicolumn{8}{|c|}{ Swanage } \\
\hline & \multicolumn{2}{|c|}{ Jun } & \multicolumn{2}{|c|}{ Jul } & \multicolumn{2}{|c|}{ Aug } & \multirow[b]{2}{*}{$\mathrm{I}_{\tau}$} & \multirow[b]{2}{*}{$\mathrm{I}_{\mathrm{S}}$} \\
\hline & $T \max$ & $\mathrm{Sh}$ & $T \max$ & Sh & $T \max$ & Sh & & \\
\hline 975 & $\begin{array}{c}19.2 \\
(+1.4)\end{array}$ & $\begin{array}{c}332 \\
(+98)\end{array}$ & $\begin{array}{c}20.5 \\
(+0.8)\end{array}$ & $\begin{array}{c}263 \\
(+26)\end{array}$ & $\begin{array}{c}21.3 \\
(+1.6)\end{array}$ & $\begin{array}{c}243 \\
(+29)\end{array}$ & +3.8 & +153 \\
\hline 1976 & $\begin{array}{c}20.6 \\
(+2.8)\end{array}$ & $\begin{array}{c}275 \\
(+35)\end{array}$ & $\begin{array}{c}22.6 \\
(+2.9)\end{array}$ & $\begin{array}{c}303 \\
(+66)\end{array}$ & $\begin{array}{c}22.0 \\
(+2.3)\end{array}$ & $\begin{array}{c}309 \\
(+95)\end{array}$ & +8.0 & +196 \\
\hline 1977 & $\begin{array}{c}15.3 \\
(-2.5)\end{array}$ & $\begin{array}{c}165 \\
(-75)\end{array}$ & $\begin{array}{c}19.2 \\
(-0.5)\end{array}$ & $\begin{array}{c}224 \\
(-13)\end{array}$ & $\begin{array}{c}19.0 \\
(+0.7)\end{array}$ & $\begin{array}{c}178 \\
(-36)\end{array}$ & -2.3 & -124 \\
\hline 1978 & $\begin{array}{c}17.0 \\
(-0.8)\end{array}$ & $\begin{array}{c}214 \\
(-26)\end{array}$ & $\begin{array}{c}18.1 \\
(-1.6)\end{array}$ & $\begin{array}{c}156 \\
(-83)\end{array}$ & $\begin{array}{c}18.7 \\
(-1.0)\end{array}$ & $\begin{array}{c}221 \\
(+7)\end{array}$ & -3.4 & -100 \\
\hline 979 & $\begin{array}{c}16.7 \\
(-1.1)\end{array}$ & $\begin{array}{c}181 \\
(-59)\end{array}$ & $\begin{array}{c}20.3 \\
(+0.6)\end{array}$ & $\begin{array}{c}249 \\
(+12)\end{array}$ & $\begin{array}{c}18.4 \\
(-1.3)\end{array}$ & $\begin{array}{c}213 \\
(-1)\end{array}$ & -1.8 & -48 \\
\hline 1980 & $\begin{array}{c}17.0 \\
(-0.8)\end{array}$ & $\begin{array}{c}219 \\
(-21)\end{array}$ & $\begin{array}{c}17.6 \\
(-2.1)\end{array}$ & $\begin{array}{c}177 \\
(-60)\end{array}$ & $\begin{array}{c}18.9 \\
(-0.8)\end{array}$ & $\begin{array}{c}186 \\
(-28)\end{array}$ & -3.7 & -109 \\
\hline 1981 & $\begin{array}{c}16.4 \\
(-1.4)\end{array}$ & $\begin{array}{c}181 \\
(-59)\end{array}$ & $\begin{array}{c}19.5 \\
(-0.2)\end{array}$ & $\begin{array}{c}185 \\
(-52)\end{array}$ & $\begin{array}{c}20.6 \\
(+0.9)\end{array}$ & $\begin{array}{c}237 \\
(+23)\end{array}$ & -0.7 & -88 \\
\hline 1982 & $\begin{array}{c}18.0 \\
(+0.2)\end{array}$ & $\begin{array}{c}230 \\
(-10)\end{array}$ & $\begin{array}{c}20.0 \\
(+0.3)\end{array}$ & $\begin{array}{c}212 \\
(-25)\end{array}$ & $\begin{array}{c}19.5 \\
(-0.2)\end{array}$ & $\begin{array}{c}199 \\
(-15)\end{array}$ & +0.3 & -50 \\
\hline 1983 & $\begin{array}{c}17.8 \\
(0.0)\end{array}$ & $\begin{array}{c}210 \\
(-30)\end{array}$ & $\begin{array}{c}22.9 \\
(+3.2)\end{array}$ & $\begin{array}{c}287 \\
(+50)\end{array}$ & $\begin{array}{c}21.3 \\
(+1.6)\end{array}$ & $\begin{array}{c}260 \\
(+46)\end{array}$ & +4.8 & +66 \\
\hline erag & 17.8 & 240 & 19.7 & 237 & 19.7 & 214 & & \\
\hline
\end{tabular}


In summary, littoral fringe algae and upper eulittoral canopy algae have their upper limits set directly by physical factors. Biological interactions such as grazing on more exposed shores and competition on sheltered shores can set the upper limit of mid and lowshore canopy forming species. 'Obligate understorey' species, primarily reds, can also have their upper limit set by physical factors acting directly. Low-shore laminarians can have their upper limit set on the shortterm directly by competition or grazing but any extension can get trimmed back during exceptionally hot (or cold - see Todd and Lewis, 1984) weather. Further work must be done on Ascophyllum.

Acknowledgements. S. J. Hawkins was primarily supported by an N.E.R.C. Studentship, though some fieldwork between 1980 and 1983 was funded by an N.E.R.C. Fellowship and Research Grant (GR3/4412) plus grants from the Manchester University Staff travel fund. Professor E. Naylor (Port Erin) and Professor E. J. Denton (Plymouth) provided laboratory space. We are most grateful to Drs. A. J. Southward, G. T. Boalch and Professor T. A. Norton for general encouragement and for improving earlier drafts. We thank the meteorological offices and personnel at Bracknell, R.A.F. Mountbatten, Ronaldsway Airport and Swanage for supplying information. R.G.H. wishes to thank the University of Liverpool Research Fund for support.

\section{LITERATURE CITED}

Boaden, P. J. S., Dring, M. T. (1980). A quantitative evaluation of the effects of Ascophyllum harvesting on the littoral ecosystem. Helgoländer Meeresunters. 33: 700-710

Bruce, J. R., Colman, J. S., Jones, N. S. (1963). Marine fauna of the Isle of Man. L.M.B.C. Mem. typ. Br. mar. Pl. Anim. 36 Liverpool University Press

Burrows, E. M. (1947). A biological investigation of the behaviour of Ascophyllum nodosum. Ph. D. thesis, University of London

Burrows, E. M., Lodge, S. M. (1950). Note on the interrelationships of Patella, Balanus and Fucus on a semiexposed coast. Rep. mar. biol. Stn Port Erin 62: 30-34

Carefoot, T. (1977). Pacific seashores. A guide to intertidal ecology. J. J. Douglas, Vancouver

Clokie, J. J. P., Boney, A. D. (1980). The assessment of changes in intertidal ecosystems following major reclamation work: framework for interpretation of algal-dominated biota and the use and misuse of data. In: Price, J. H., Irvine, D. E. G., Farnham, W. F. (ed.) Systematics association, Spec. Vol. N. 17(b) The shore environment, Vol. 2 , Ecosystems. Academic Press, London, p. 609-675

Connell, J. H. (1972). Community interactions on marine rocky intertidal shores. Ann. Rev. Ecol. System. 3: 169-192
Dayton, P. K. (1975). Experimental evaluation of ecological dominance in a rocky intertidal algal community. Ecol. Monogr. 45: 137-159

Hawkins, S. J. (1979). Field studies on Manx rocky shore communities. Ph. D. thesis, Liverpool University

Hawkins, S. J. (1981a). The influence of Patella grazing on the fucoid/barnacle mosaic on moderately exposed rocky shores. Kieler Meeresforsch. 5: 537-543

Hawkins, S. J. (1981b). The influence of season and barnacles on the algal colonisation of Patella vulgata exclusion areas. J. mar. biol. Ass. U.K. 61: 1-15

Hawkins, S. J., Harkin, E. (in submission). The effects of experimental canopy removal in rocky low-shore and shallow sub-tidal communities (submitted to Botanica mar.)

Hawkins, S. J., Hartnoll, R. G. (1983a). Grazing of intertidal algae by marine invertebrates. Oceanogr. mar. Biol. A. Rev. 21: 195-282

Hawkins, S. J., Hartnoll, R. G. (1983b). Changes in a rocky shore community: an evaluation of monitoring. Mar. environ. Res. 9: 131-181

Lewis, J. R. (1964) The ecology of rocky shores. English Universities Press, London

Lubchenco, J. (1980). Algal zonation in the New England rocky intertidal community: an experimental analysis. Ecology 61: 333-344

Lubchenco, J., Cubit, J. (1980). Heteromorphic life histories of certain marine algae as adaptations to variations in herbivory. Ecology 61: 676-687

Menge, J. L. (1975). Effect of herbivores on community structure of the New England rocky intertidal region: distribution, abundance and diversity of algae. Ph. D. thesis, Harvard University, Cambridge, Mass.

Parke, M., Dixon, P. S. (1976). Check-list of British marine algae: third revision. J. mar. biol. Ass. U.K. 56: 527-594

Schonbeck, M. W., Norton, T. A. (1978). Factors controlling the upper limits of fucoid algae. J. exp. mar. Biol. Ecol. 31: 303-313

Schonbeck, M. W., Norton, T. A. (1980). Factors controlling the lower limits of fucoid algae on the shore. J. exp. mar. Biol. Ecol, 43: 131-150

Southward, A. J. (1953). The ecology of some rocky shores in the south of the Isle of Man. Proc. Trans. Liverpool biol. Soc. 59: $1-50$

Southward, A. J. (1958). The zonation of plants and animals on rocky sea shores. Biol. Rev. 33: 137-177

Southward, A. J., Southward, E. C. (1978) Recolonization of rocky shores in Cornwall after use of toxic dispersants to clean up the Torrey Canyon spill. J. Fish. Res. Bd Can. 35: 682-706

Todd, C. D., Lewis, J. R. (1984) Effects of low air temperature on Laminaria digitata (L.) in south-western Scotland. Mar. Ecol. Prog. Ser. 16: 199-201

Underwood, A. J. (1979) The ecology of intertidal gastropods. Adv. mar. Biol. 16: 1-109 